\title{
研削仕上面あらさの生成機構 ${ }^{*}$
}

\section{一仕上面あらさに及ぼすドレッシング特性の統計学的考察—}

\author{
長谷川素由** 河村末 久** 小野 浩 二**
}

The Generating Mechanism of the Ground Surface Roughness

\author{
-A Statistical Analysis of Dressing Characteristics \\ to the Ground Surface Roughness- \\ Motoyoshi Hasegawa, Suehisa Kawamura, Kōji Ono
}

\begin{abstract}
There are many discrepancies in opinions hitherto about the probability density function of cutting edges after dressing treatment. The present paper deals with the effect of the dressing treatment on the grinding wheel and ground surface. The theoretical explanation was offered for the distribution curve of cutting edges after dressing and the root mean square roughness of ground surface. The calculated values based on the theoretical explanation show good agreement with experimental values. The theory shows that when the grinding wheel is dressed by the diamond dresser with a conical apex, the distribution curve of cutting edges changes from the rectangular distribution to the parabolic one with the increase of the dressing number and the root mean square of surface ground with it can be calculated theoretically.
\end{abstract}

\section{1. は じめに}

研削仕上面あらさの生成機構については, 関与する要 因の多様性からいまだ明確な解析が得られていない。従 来, 幾们学的解析の面では佳藤 ${ }^{1)}$, 小野 ${ }^{21}, \mathrm{Shaw}^{3)}$, 越

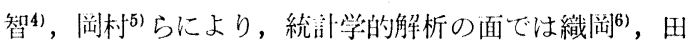
中ら $5^{71}$, 佳田 $5^{81}$, 松井ら 91 , 築添ら ${ }^{101} 0$ 研究がある.

最近の解析では, 切れ刃のランダム性を考虑して統計 学的乎法が盛んに用いられている.しかし, これらの理 論解析をみると, 解析の出発点となる切饥刃高さ分布の 分布形一つを取上げてみても統一見解が存在しない.

本報告は, 研削仕上面あらさの生成機構を再検討して 統計学的研削像をより明確にする意味からドレッシング 後の切狆高さ分布の生成過程と, 同じ砥石で研削した 場合に創成されるあらさの生成過程について統計学的洘 察を試み，理論の妥当性を検証したものである。

\section{2. 理 論}

\section{1 単石ドレッサによるランダムな切れ刃の} 生成過程

研削仕上面あらさの生成機構を解明与るにあた

* 原稿受付 昭和 48 年 8 月 4 日. 昭和 48 年度精機 学会春季大会学術講演会（昭和 48 年 4 月 5 日）に て発表.

** 正会員 防衛大学校 (横須賀市走水 1-10-20)
っては，まずドレッサで砥石をドレッシングしたときに 生成される切れ刃高さ分布を知る必要がある。ここで は，単石ドレッサで低石をドレッシングする場合を取上 げる・

解析にあたっては, (1) 砥石とドレッサの振動は無視で きるほど小さく，(2) ドレッサの形状注角 $2 \varphi$ の円すい 形状で, (3)ドレッサが砥石と接触した部分は砥粒の分布 に関係なくすべてドレッシングされ苟ものと考える。さ て，一般解を導くにあたって，単石ドレッサで砥石を 3 回ドレッシングした場合から考察寸る.図 1 において砥 石表面を互いに独立に 3 回ドレッシングしたとき，各回 数に応じて生成される切れ刃の幾何学的形状は図のよう に変化して最後に斜線の部分が切れ刃として残る.この 場合, ドレッサの通過回数に対する切れ刃の幾何学的形 状の変化すなわちドレッシングに対忍する切れ刃高さ分

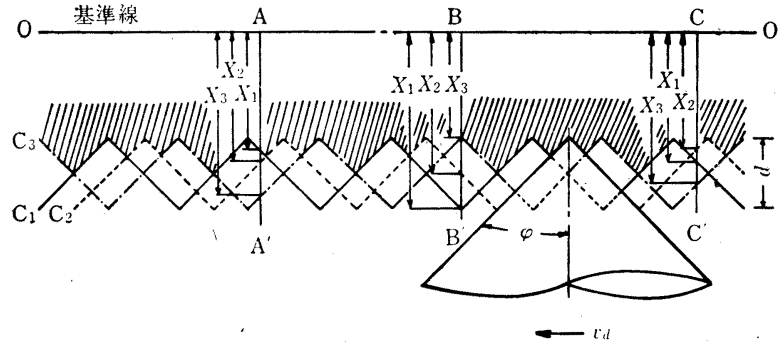

図 1 ドレッシング機構 
布は，砥石の内部によった任意の基隼 $0 O^{\prime}$ からドレ， サが通過してててきたおし山の軌跡まて测，た距離 $X_{\imath}(\imath$ はドレ，サが通過した軌跡の順序を示す）の分布と圭さ

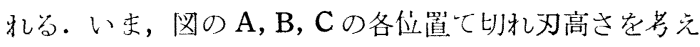
ると, 位置 $\mathrm{AA}^{\prime}$ ては $X_{1}<X_{2}<X_{3}$, 位置 $\mathrm{BB}^{\prime}$ ては $X_{3}<$ $X_{2}<X_{1}$, 位置 $\mathrm{CC}^{\prime}$ で $X_{2}<X_{1}<X_{3}$ の関係が成立して いる. この関係からわかるように切れ刃高さ恃基隼線 $\mathrm{OO}^{\prime}$ からねじ山の軌跡まて則った距離のうち最小の距離 て示される.したがって，一般に互いに独立に $m$ 回ド レッシングした場合の切れ刃高さほほ，一般形としては ドレッシング前の砥石のあらさを考慮する必要がるか ら, いまこれを確率变数 $X_{0}$ て表せは, 四 1 から結局切 れ刃分布は $(m+1)$ 個の確率変数 $X_{0}, X_{1}, X_{2}, \quad X_{m}$ を大きさの小さいものから大きいものへ順に並べてつく った順序統計量 $X_{(0)}<X_{(1)}<X_{(2)}<\quad<X_{(m)}$ に関する 最小值の分布に相当する.したがって, 同じ基凖線から

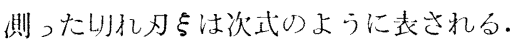

$$
\xi=\min \left(X_{0}, X_{1}, X_{2}, \quad, X_{m}\right)
$$

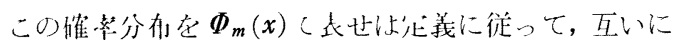

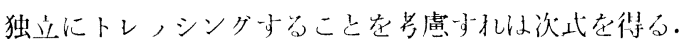

$$
\begin{aligned}
\Phi_{m}(x) & =P_{r}\left\{\min \left(X_{0}, X_{1}, \quad X_{m}\right) \leqq x\right\} \\
& =1-P_{r}\left\{X_{0} \geqq x\right\} \cdot P_{r}\left\{X_{1} \geqq x\right\} \quad P_{r}\left\{X_{m} \geqq x\right\} \\
& =1-P_{r}{ }^{m}\{X \geqq x\} \cdot P_{r}\left\{X_{0} \geqq x\right\} \\
& =1-\left[1-P_{r}\{X \leqq x\}\right]^{m} \cdot\left[1-P_{r}\left\{X_{0} \leqq x\right\}\right]
\end{aligned}
$$

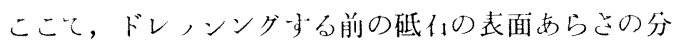
布圭 $\mathrm{F}_{0}(x)$ て，またドレ，サか片いに独立に通搁したとき に低不に構成される机し山形状りし机刃の分仍を $\mathrm{F}(x)$ て袁忆，単低ドレ，サてドレ，シングした埸合に生成

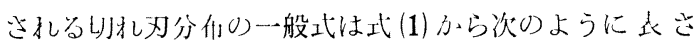
れる。

$$
\Phi_{m}(x)=1-[1-\mathrm{F}(x)]^{m} \cdot\left[1-\mathrm{F}_{0}(x)\right]
$$

いま，ドレ,シング特性の影響を明らかにするため， 切れ刃は低石の半径方向, 円周方向, 幅方向に分布して いるがこれらのうち前 2 者を取上け解析を簡単化する と, 式 (2)で $\mathrm{F}_{0}(x)$ を考虑する必要がなくなるから次式 を得る*.

$$
\Phi_{m}(x)=1-[1-\mathrm{F}(x)]^{m}
$$

式 $(2)^{\prime}$ の $\mathrm{F}(x)$ は, ドレッサの形状によって决まるが, 先の仮定と図 1 からわかるように砥石の切れ刃分布幅す なわちねじ山の高さを $d$, 砥石の回転数を $N$, ドレッサ

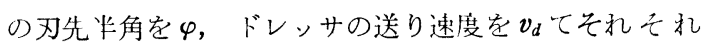

* 式 (2) において, ドレ,シング前の切れ刃分布の分布形が 一样分布でる場合，トレンシング前の表面あらさを考虐 して, $(m-1)$ 回ドレノシンクしたと読みかえることもで きる。

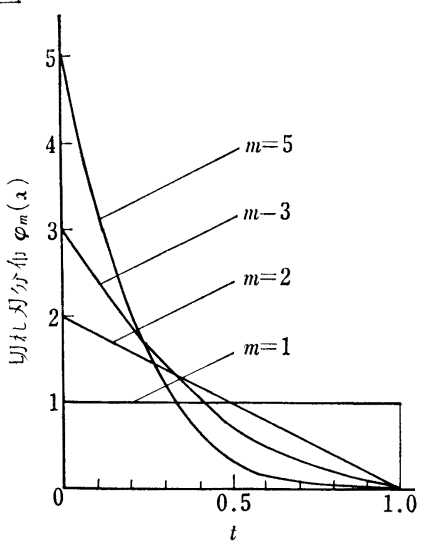

图 2 トレノシングによる切れ刃分布の变化

表せは次のようになる。

$$
\begin{aligned}
& \mathrm{F}(x)=\frac{x}{d} \quad(0<x<d) \\
& \mathrm{f}(x)=\frac{d \mathrm{~F}(x)}{d x}=\frac{1}{d} \quad(0<x<d) \\
& d={ }_{2 N} \cot \varphi
\end{aligned}
$$

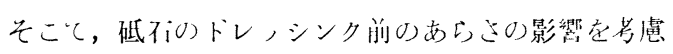
しない場介は，式 $(3) \sim(5)$ と式 $(2)^{\prime}$ を変形してドレ, シ

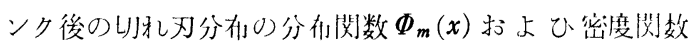
$\varphi_{m}(x)$ は下吔のように水わられる。

$$
\begin{gathered}
\Phi_{m}(x)=1-\left(1-\frac{x}{d}\right)^{m} \quad(0<x<d) \\
\varphi_{m}(x)=\frac{d \Phi_{m}(x)}{d x}-m\left(\begin{array}{c}
1 \\
d
\end{array}\right)\left(1-\frac{x}{d}\right)^{m} 1 \\
\quad(0<x<d)
\end{gathered}
$$

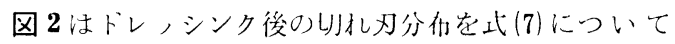
調算した結果こある。 $\varphi_{m}(x)$ は $m$ 0増加とともに放物線 になる。

\section{2 研削仕上面あらさに関する解析}

ドレノシング後の切れ刃分布が導出されたした，この ような切れ刃をもつ砥石て研削した場合の被削材の仕上 面あらさについて解析する. 図 1 について同怺に考える と, 砥石円周方向に存在する切れ刃はドレ,ンングされ ても互いにランダム性を保持するから，仕上面あらさの 分布は同し基隼線から測った距嚁の最大值の分布に相当 与る.したがって, 研削された仕上面あらさの分布関数 $\mathrm{G}(x)$ 扩よびその毕度関数 $\mathrm{g}(x)$ は次式のように与えられ 万.

$$
\mathrm{G}(x)=\left\{\Phi_{m}(x)\right\}^{n}=\left\{1-\left(1-\frac{x}{d}\right)^{m}\right\}^{n}
$$




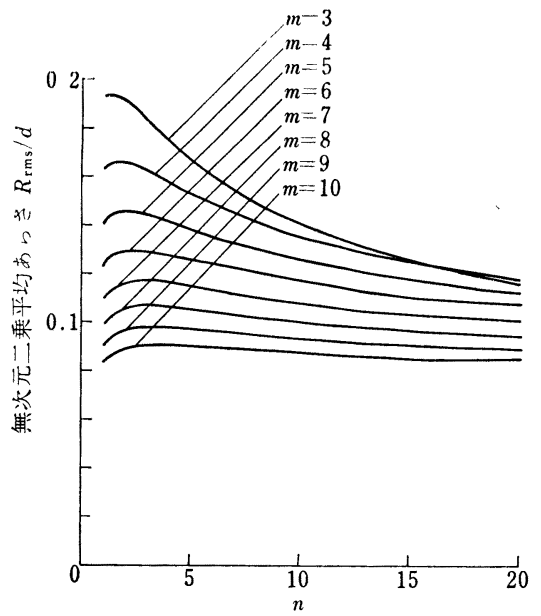

图 3 サンプルサイズと無次元二乗平均あらさ

$$
\begin{aligned}
\mathrm{g}(x) & =\frac{d \mathrm{G}(x)}{d x}=n \varphi_{m}(x)\left[\Phi_{m}(x)\right]^{n-1} \\
& =\frac{m n}{d}-\sum_{k-0}^{n-1}\left(\begin{array}{c}
n-1 \\
k
\end{array}\right)(-1)^{n-k-1} d^{m h}(d-x)^{m(n-k)-1}(9)
\end{aligned}
$$

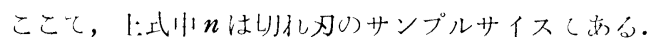

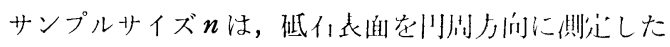
断面曲緗よのし狄风ピーク值は亚いに独立と考えてよい

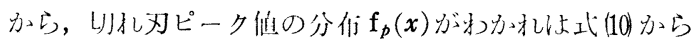
水め叔方。

$$
n=\frac{1}{L_{p}} \cdot \frac{V}{v} \sqrt{D A} \cdot N_{p} \cdot \int_{0}^{d} \mathrm{f}_{p}(x) \mathrm{d} x
$$

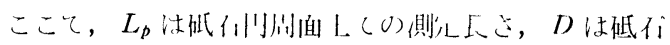

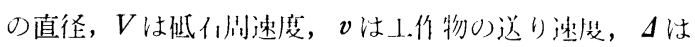

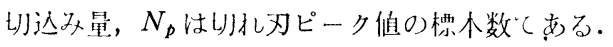

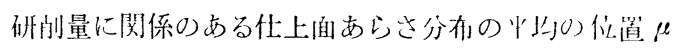
は次式て衣せる。

$$
\begin{aligned}
\mu & =\int_{0}^{d} x \cdot \mathrm{g}(x) \mathrm{d} x \\
& =n \cdot d \sum_{k=0}^{n-1}\left(\begin{array}{c}
n-1 \\
k
\end{array}\right)(-1)^{n-k-1} \cdot \overline{(n-k)[m(n-k)+1]}
\end{aligned}
$$

そこて, 表面あらさの統計的性質を表すらえからも重 要な意義のある二乘平均あらさ $R \mathrm{~ms}$ 它求めると次のよ うに導出てきる.

$$
\begin{aligned}
R_{\mathrm{r} \mathrm{m}}= & {\left[\int_{0}^{d} x^{2} \mathrm{~g}(x) \mathrm{d} x-\mu^{2}\right]^{1 / 2} } \\
= & {\left[2 d^{2} n \sum_{k=0}^{n-1}\left(\begin{array}{c}
n-1 \\
k
\end{array}\right) \overline{(n-k)[m(n-k)+1][\bar{m}(\overline{n-k)+2]}}\right.} \\
& \left.-\left\{n d \sum_{k=0}^{n-1}\left(\begin{array}{c}
n-1 \\
k
\end{array}\right) \frac{(-1)^{n-k-1}}{(n-k) \overline{[m(n-k)+1}]}\right\}^{2}\right]^{1 / 2}
\end{aligned}
$$

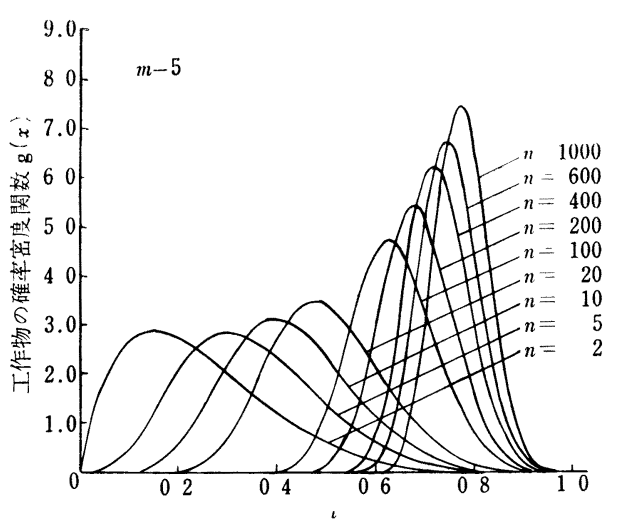

凶4 仕上面あらさの確率密度関数

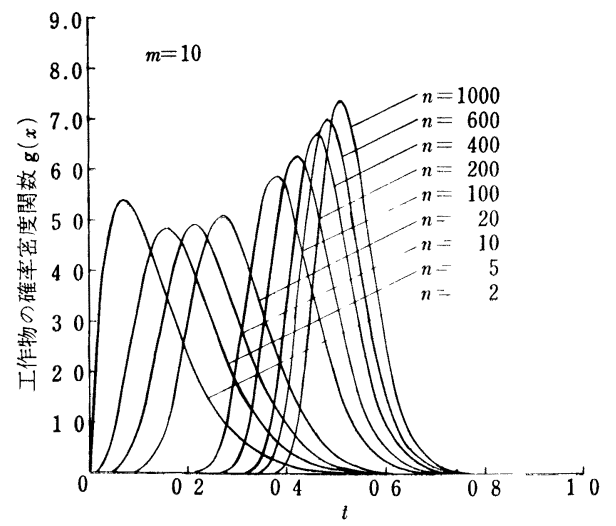

目 5 仕上面あらさの確率密度関数

図 3,4,5 は式 (9) こ(12)について $t=x / d$ と無次元化学

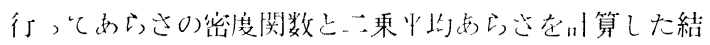

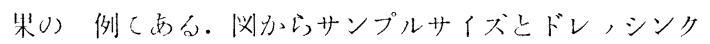

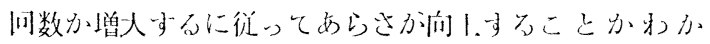
z.

\section{3. 実 験}

\section{1 実験装置および実験条件}

実験に 朔本 PSG-6 E 型油圧駆動精密中面研削盤を 使用した. 低石円周表面の切れ刃ピーク值の分布測定に は, 一定速度て送れる送り装置を圾作して, この装置て 砥石を軸方向に一定速度でドレ, シングしたのち, 小坂 式駆動テーブルで砥石を定速で回転させながら小坂式 SE 3 型表面あらさ楛で測定した。 またダイヤモンドド レッサを使用したか各実験ごと取替えて使用した。

\section{2 被削材}

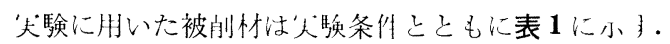
被削材の衣面あらさは研削加工によって $R_{\max } \doteqdot 0.2 \mu \mathrm{m}$ 程度に仕上げたのち, 熱処理温度 $800^{\circ} \mathrm{C} て ゙ 60$ 分保持し たのち真空焼鈍を行った。 
表 1 甚験 条 件

\begin{tabular}{|c|c|c|}
\hline \multicolumn{2}{|c|}{ 研㴥 盤 } & OKAMOTO PSG-6 E 型平面研削盤 \\
\hline 砥 & $\begin{array}{l}\text { 䅜 類 } \\
\text { 周速 度 } \\
\text { 直 径 }\end{array}$ & $\begin{array}{l}\text { A } 46 \mathrm{M} 6 \mathrm{~V}, \mathrm{~A} 60 \mathrm{M} 6 \mathrm{~V}, \text { A } 80 \mathrm{M} 6 \mathrm{~V} \\
1880 \mathrm{~m} / \mathrm{min} \\
20 \mathrm{~cm}\end{array}$ \\
\hline 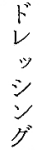 & $\begin{array}{l}\text { ドレッサ } \\
\text { 送り速度 } \\
\text { 切込多量 }\end{array}$ & $\begin{array}{l}\text { 単石ダイヤモンドドレッサ（半頂觕 } 46^{\circ} \sim \\
63^{\circ} 30^{\prime} \text { ) } \\
3.04 \mathrm{~cm} / \mathrm{min} \\
\text { 切込タ } 20 \mu \mathrm{m} \text { でワンパスを } 5 \text { 回 }\end{array}$ \\
\hline \multicolumn{2}{|c|}{ 工作汤 } & 合金工具銅 SKS $3\left(H_{V}=178\right)$ \\
\hline \multicolumn{2}{|c|}{ テーブル速度 } & $7.69 \mathrm{~m} / \mathrm{min}$ \\
\hline \multicolumn{2}{|c|}{ 碓削㴵 } & 皮 ᄂ \\
\hline
\end{tabular}

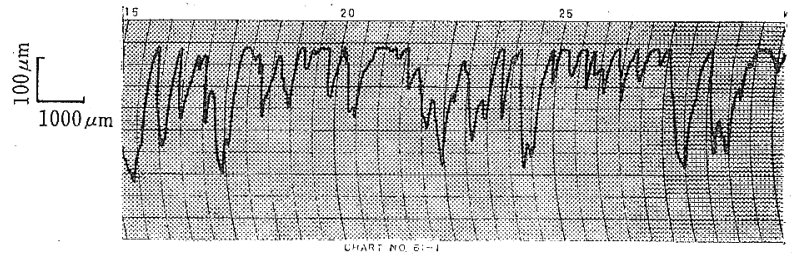

(a) A46M6V

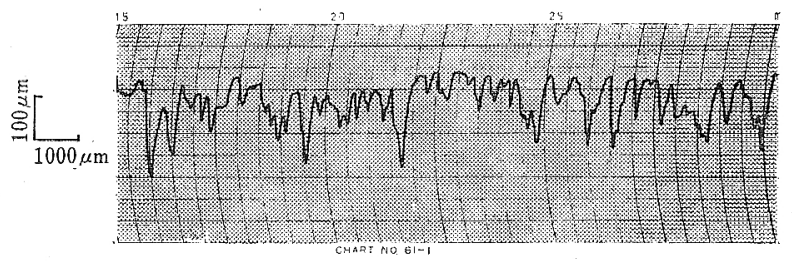

(b) A60M6V

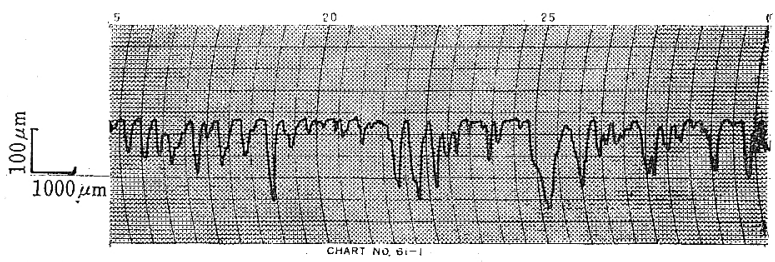

(c) $\mathrm{A} 80 \mathrm{M} 6 \mathrm{~V}$

図6 诋石円周表面のプロフィル

\section{4. 実験結果および考察}

\section{1 碈石円周方向における切れ刃分布}

図 6 (a)，(b)，(c) はドレッシング後の砥不表面を表面あ らさ計で円周方向に測定したプロフィル宗す。

図 7 (a)，(b)，(c)はこのプロフィルから比れ犯ピータ值 の標本分布打上びその密度関数究求めたものである。各

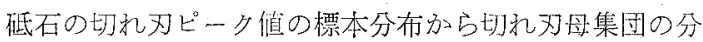
布形夌推定吉をにあたり，下記の Gamma 分布形で近似 した。

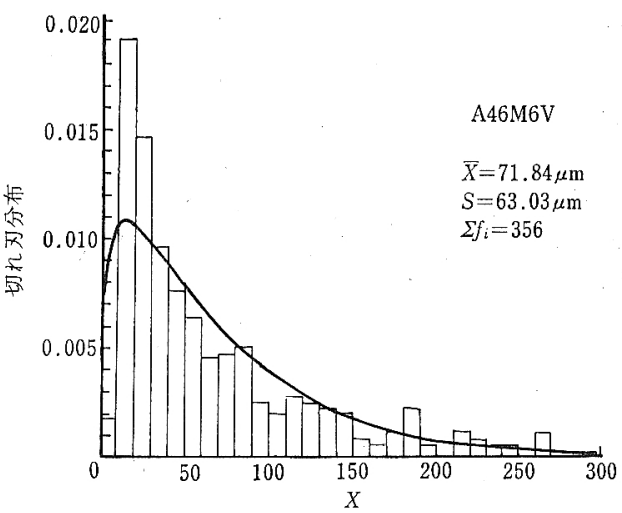

(a)

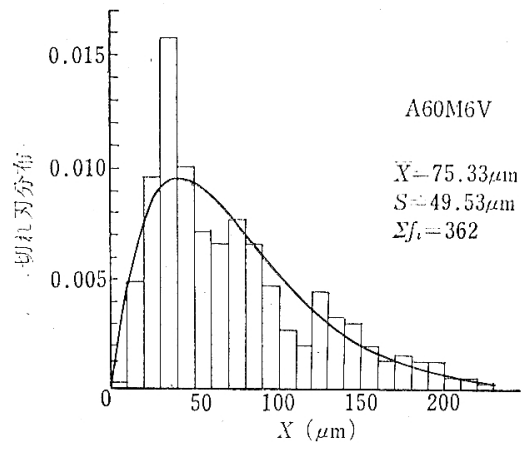

(b)

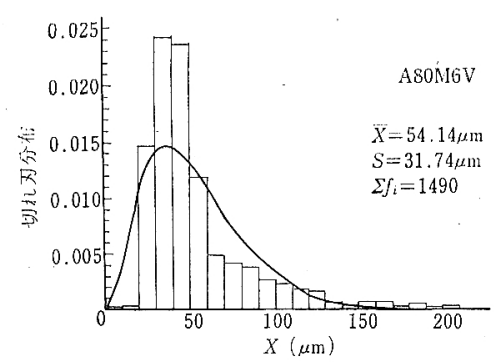

(c)

図7切机刃分棑

表 2 砥石パラメータ

\begin{tabular}{c|c|c|c|c}
\hline 低 石 & $r$ & $\lambda$ & $\begin{array}{c}\text { 備 } \\
\text { 分布幅 } \\
(\mu \mathrm{m})\end{array}$ & $\begin{array}{c}\text { 考 } \\
\left(\begin{array}{l}\text { 則定長 } \\
(\mathrm{mm})\end{array}\right.\end{array}$ \\
\hline A 46 M 6 V & 1.29 & 0.018 & 270 & 100 \\
A 60 M 6 V & 2.31 & 0.028 & 230 & 100 \\
A 80 M 6 V & 3.37 & 0.054 & 210 & 300 \\
\hline
\end{tabular}

$\mathrm{f}_{p}(x)=\frac{\lambda^{r}}{\Gamma(r)} \exp (-\lambda x) \cdot x^{r-1}$ 
研削仕上面あらさの生成機構

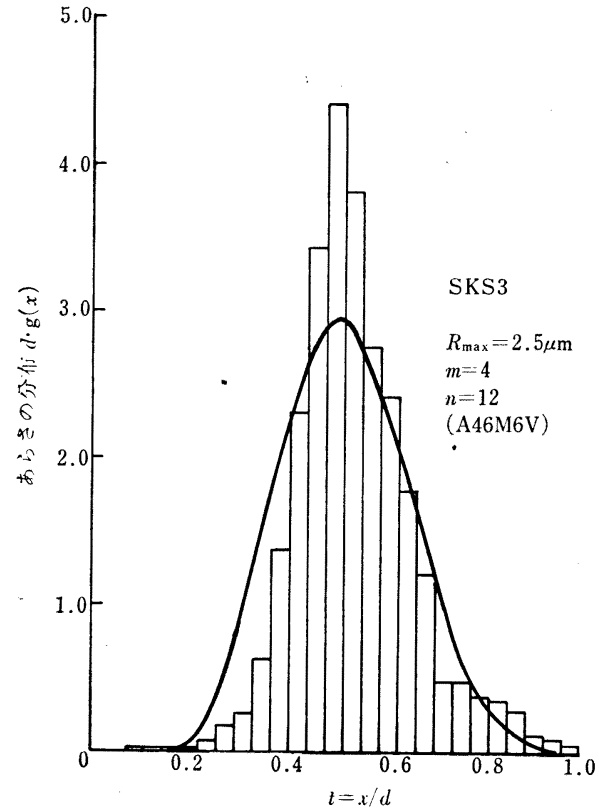

图 8 研削仕上面あらさの分布

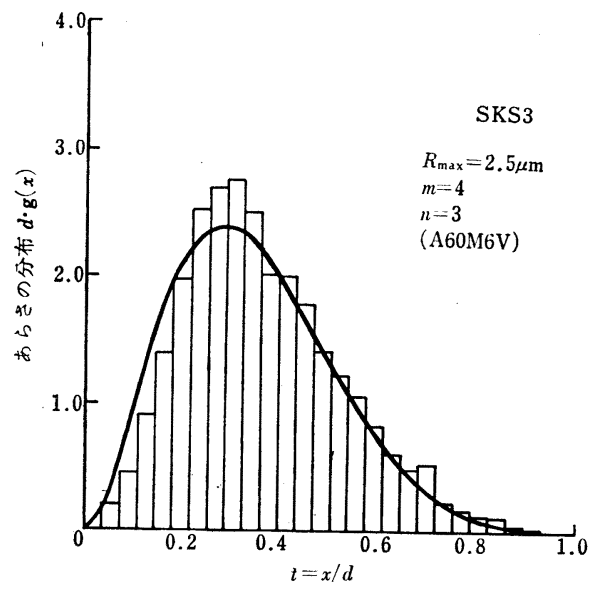

図 9 研削仕上面あらさの分布

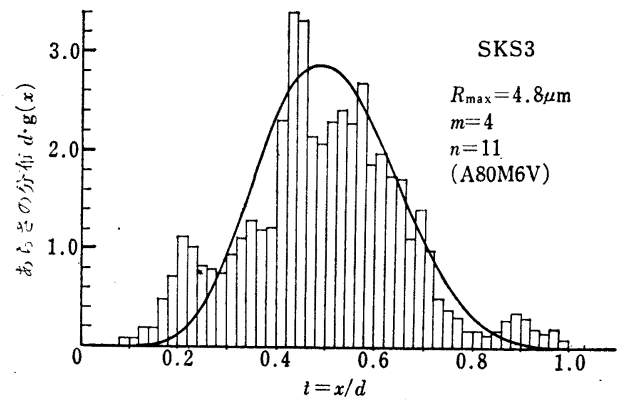

図 10 研削仕上面あらさの分布

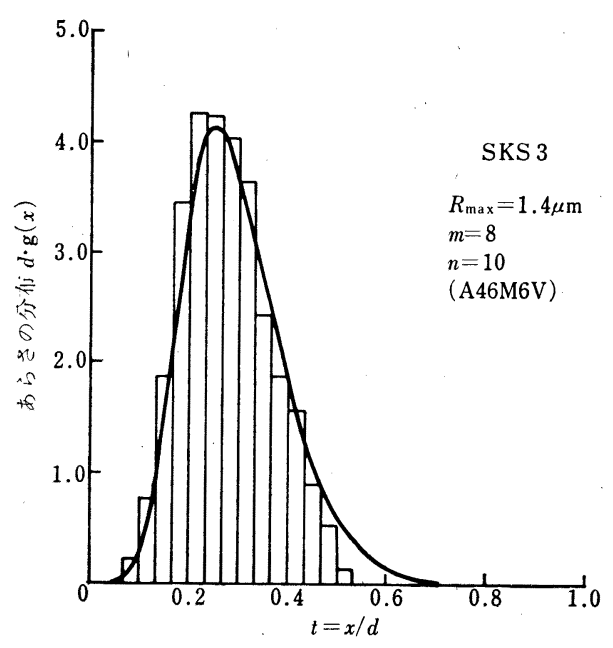

図 11 研削仕上面あらさの分布

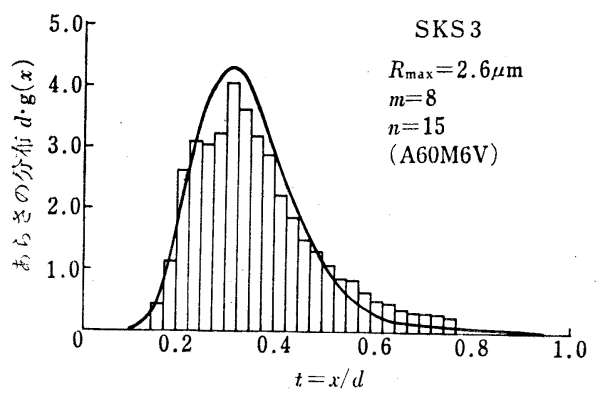

图 12 研削仕上面あらさの分布

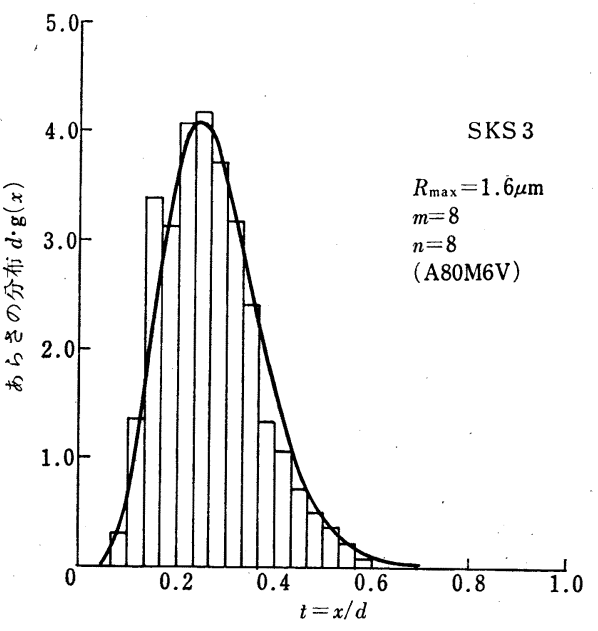

图 13 研削仕上面あらさの分布 
表 3 実 験 結 果

\begin{tabular}{|c|c|c|c|c|c|c|c|}
\hline 砥 & 石 & A 46 & $16 \mathrm{~V}$ & A 60 & $16 \mathrm{~V}$ & A 80 & $46 \mathrm{~V}$ \\
\hline ドレッシ & グ回数 $m$ & 4 & 8 & 4 & 8 & 4 & 8 \\
\hline サンプル+ & -イズ $n$ & 12 & 10 & 3 & 15 & 11 & 8 \\
\hline 切込及量 & $(\mu \mathrm{m})$ & 7 & 3 & 4 & 10 & 7.3 & 6 \\
\hline ドレッサシ & 頂角 $\varphi$ & $63^{\circ} 30^{\prime}$ & $61^{\circ}$ & $62^{\circ} 40^{\prime}$ & $53^{\circ} 37^{\prime}$ & $46^{\circ}$ & $60^{\circ} 15^{\prime}$ \\
\hline 切れ刃高 & $d(\mu \mathrm{m})$ & 2.7 & 3.0 & 2.3 & 4.0 & 5.24 & 3.1 \\
\hline 仕上面 & $\begin{array}{c}\text { 実 測 值 } \\
(\mu \mathrm{m})\end{array}$ & 0.324 & 0.266 & 0.445 & 0.509 & 0.791 & 0.292 \\
\hline$R_{\mathrm{rms}}$ & $\begin{array}{c}\text { 理 論 值 } \\
(\mu \mathrm{m}))\end{array}$ & 0.292 & 0.301 & 0.454 & 0.386 & 0.928 & 0.317 \\
\hline
\end{tabular}

生成機構を統計学的に解析した結果次のよ うなことが明らかになった。

（1）低不周表面にある圳れ用がランダ ムであることから仕上面あらさの生成 機構に及ぼすドレッシング特性の理論 解析には順序統計量の概念を一貫して 用いることができる.

(2) ドレッシング条件と比れ刃ピーク値 の分布がわかればドレッシング特性を 考慮した仕上面あらさの密度関数, 分 布関数，分散，二乗平均あらさが理論
標準偏差，標本数を示している.また表 2 は式 (13)のパ ラメータについて実験結果から推定した値である．測定 にあたって切れ刃分布範囲を切れ刃全領域にとって，切 込み領域に限定しなかったのは本解析では切れ刃母集団 そのものの分布形を推定したいためである.さて切れ刃 分布の分布形としては，従来ピーク值分布の分布形は Envelopeの分布と言われ，理論的には Rayleigh 分布 ${ }^{11}$ が子想される。

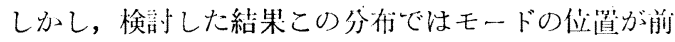
にき与きてその密度は過大に高く本実験軼囲では分布 形として妥当ではなかった。 もちろん，Cartwright, Longuet-Higgins らの高次モーメントを用いたピーク

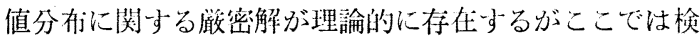
討しなかった。

以上の結果，砥不倜方向の切れ刃ピーク值分布の分 布形は，指数タイプのうち原点を0に選べる Gamma 分 布形でかなりよく表せることがわ林。

\section{2 研削仕上面あらさ}

図 8〜13 は砥石 A $46 \mathrm{M} 6 \mathrm{~V}, \mathrm{~A} 60 \mathrm{M} 6 \mathrm{~V}, \mathrm{~A} 80 \mathrm{M} 6 \mathrm{~V}$ で 被削材SKS 3 を研削した場合の仕上面あらさの標本分布 と式 (9)で計算した理論曲線とを示す. また,表 3 はこれ らの実験結果を整理して二乗平均あらさの実測值と理論 值とを比較できるように示したものである．この結果か らわかるように,式(9)で計算した仕上面あらさの密度関 数は比較的よく実測值と適合しているとともに, 式 (12) で 求めた二乗平均あらさに関しても理論值と実測值とがか なりよい対応を示すことがわかる．理論值が実測值より も小さい值を示すのはドレッシング前の砥石表面のあら さの影響によるものと考えられる. ところで, 表 3 の切 込夕量 $\Delta$ は，被削材の前加工表面と研削後の仕上面の間 にできる段を表面あらさ計で測定して求めた值である.

\section{5. 結 論}

研削仕上面あらさの生成機構をドレッシング後の切れ 刃高さ分布の生成過程から考察し, 研削仕上面あらさの
的に推定できる.

（3）砥石（粒度 46〜80 番) の切れ刃ピーク值分布の分 布形は指数夕イプで表されるが，理論的に予想され る Rayleigh 分布よりむしろ Gamma 分布がよく適 合する.

(4) ドレッシング後の比れ刃分优の理論分在形は，ド レッシング回数が増大するに良って放物線分死形を 亦占.

（5）ランダムサンブルサイズとドレッシング|数とが 伐上面あらさの问上に及ぼす影響老比較与るとドレ ッシング回数の効果のガがはるかに大きい.

最後に本研究を遂行するに当たって垁験およびその整 理にご協力いただいた国分政夫，太朋康和，宫叮话次， 出代雅彦の諸录に対し厚くお礼中し上げます。.

\section{参考 文 献}

1）佐滕健児：研削理論(第 2 報), 精密機械, 16, 4·5(1950) 117.

2）小野浩二：と粒切れ刃の形状ならびに分布が研㴥仕上面 あらさに及ぼす影響，日本機械学会論文集，30, 211 (1964) 361.

3) C. T. Yang \& M. C. Shaw: The Grinding of Titanium Alloys, Trans. ASME, 77, July (1955)645.

4) 越智隆冬: 研削機構の研究 (第 2 報), 精密機械, 23, 7 (1957) 308.

5) 岡村健二郎, 中島利勝: 砥粒切れ刃による切削現象の研 究 (第 1 報), 精密機械, 32, 4 (1966) 287 .

6）織岡貞次郎：確率論を応用した研削仕上面創成の理論, 日本機械学会誌，63，499 (1960) 1185.

7）田中義信, 井川直哉：ダイヤモンド砥石による研削に関 する研究 (第 2 報), 精密機械, 27, 2 (1961) 86.

8）佐田登志夫, 久保盛唯: 精密加工における表面あらさの 形成過程, 精密機械, 32, 2 (1966) 118 .

9）松井正己，庄司克雄：研削仕上面あらさに関する一考 察, 機械の研究, 19, 10 (1967) 1341.

10）築添 正, 久門輝正, 長欲川素由: 表面あらさの生成機 構 (第 1 報)，日本機械学会論交集，38，307 (1972) 633.

11) D. E. Cartwright \& M.S. Longuet-Higgins: The Statistical Distribution of the Maxima of a Random Function, Proc. Roy. Soc. Lond., Ser. A, 237 (1956). 